\title{
THE EFFECT OF BACTERIAL METABOLISM ON THE ANTIGENIC PROPERTIES AND SEROLOGIC REACTIONS OF BACTERIA *
}

\author{
J. P. SIMONDS
}

From the Department of Pathology of Northwestern University Medical School, Chicago

The specific effect of the presence of fermentable sugar upon bacterial metabolism, as shown by Kendall and Farmer, ${ }^{1}$ and its equally definite effect upon the production of proteolytic ferments by B. proteus, as shown by Kendall and Walker, ${ }^{2}$ made it a matter of interest and perhaps of practical importance to determine whether growth in media containing utilizable carbohydrate would affect the antigenic properties of bacteria, or would in any way influence their reaction to normal and immune sera.

To this end, tubes of sugar-free broth and of $1 \%$ dextrose broth were inoculated from the same stock culture of B. typhosus. Daily transfers were made into corresponding media for a period of 2 weeks. At the end of this time cultures were made on sugar-free and dextrose agar slants, incubated for 24 hours, and then placed in the refrigerator $(5$ to $10 \mathrm{C}$.) for preservation. The sugar-free culture was designated "T. P.," the dextrose culture "T. D."

Two observations may be noted incidentally: (1) The growth of "T. D." was very much more abundant in dextrose media than that of "T. P." on sugar-free media-an observation which is not by any means new. (2) There was a definite tendency for "T. D." to die out rather quickly at first, whether the cultures were kept in the refrigerator or at room temperature, so that it was necessary to make fresh inoculations at least once a week. After cultivation for from 4 to 6 months on dextrose media, growth could easily be obtained by inoculation from the sediment of dextrose broth cultures from 3 to 4 weeks old.

To determine the effect of sugar on the antigenic properties of B. typhosus, healthy rabbits were injected intraperitoneally, one with a single large dose of a suspension of "T.D." and one with the same

* Received for publication July 3, 1915.

1. Jour. Biol. Chem., 1912-13, 12, pp. 13, 215, 219.

2. Tr. Chicago Path. Soc., 1915, 9, p. 320. 
of "T. P.," heated to $56 \mathrm{C}$. for 30 minutes. On the tenth day thereafter the animals were bled and the serum obtained. The antibody content of these sera for the homologous and heterologous strains was determined.

\section{AGGLUTININS}

Numerous attempts have been made to modify the agglutinogenic and agglutinative properties of bacteria.

Kirstein ${ }^{3}$ found that typhoid bacilli when grown on urine agar were more readily agglutinated, and when grown in serum broth slightly less readily agglutinated, than when grown in ordinary media. He was unable to produce any permanent loss of agglutinability in the strains studied by him. Gloessner ${ }^{4}$ reported that the presence of sugar in culture media had an unfavorable influence on the agglutinogenic properties of B. typhosus but had little or no effect upon agglutinability. Sehrwald ${ }^{\mho}$ claimed that B. typhosus grown upon potato was more readily and more rapidly agglutinated than when cultivated on any other medium. Eisenberg ${ }^{0}$ was unable to confirm this finding of Sehrwald's. Eisenberg grew B. typhosus for several generations in broth at $42 \mathrm{C}$. and found a reduction in agglutinative, but not in agglutinogenic, properties.

Porges and Prantschoff ${ }^{2}$ injected a suspension of living typhoid bacilli into the ear vein of a rabbit, and 35 days later isolated the same organism from the gall-bladder of the animal. They did not find that this organism agglutinated at all differently from the original culture which had been kept growing on ordinary media. Altmann and Rauth, ${ }^{8}$ by growing B. coli for several generations on "Carbol-agar," produced a strain which would not agglutinate with the immune serum of the original strain, nor would the immune serum of this organism agglutinate the original strain of colon bacillus from which it came. Bordet and Sleeswijk $\mathrm{k}^{\ominus}$ grew the bacillus of pertussis on plain and hemoglobin agar. The serum of rabbits inoculated with the plain agar strain would agglutinate only that strain; while the serum of rabbits inoculated with organisms grown on hemoglobin agar would agglutinate both plain and hemoglobin agar strains.

Theoretically, there are two possible ways in which differences in metabolism of bacteria due to the presence of fermentable sugar may affect agglutination. The agglutinogenic substance may be reduced or modified so that injection of the organisms into animals will cause the production of no agglutinins, or of a serum of low titer only. Or the agglutinable substance may be diminished or changed so that even in the presence of sera of high titer the organisms will not agglutinate. It appears from the literature that it is very difficult to affect changes of either kind in a given strain of bacteria. Such changes as are pro-

3. Ztschr. f. Hyg. u. Infections-Krankh., 1904, 46, p. 229.

4. Ztschr. E. exper. Path. u. Therap, 1905, 1. p. 640.

6. Centralbl. f. Bakteriol., I, O., 1906, 41, pp. 752, 823.

7. Ibid., p. 658 .

8. Ztschr. f. Immunitätsforsch., 1910,7, p. 629.

9. Ann. de l'Inst. Pasteur, 1910, 24, p. 476. 
duced are, as a rule, quantitative rather than qualitative, and transitory rather than permanent. In general, our results accord with this statement. But the presence of utilizable sugar does appear to have a very definite and constant effect upon agglutination, as shown by the results here reported.

TABLE 1

Effect of Bacterial Metabolism upon the Agglutinogenic and Aggiutinative Properties op B. Typhosus

\begin{tabular}{|c|c|c|c|c|c|c|c|c|c|}
\hline \multirow{2}{*}{ Culture } & \multicolumn{9}{|c|}{ T. D. Immune Serum } \\
\hline & $1-50$ & $1-100$ & $1-250$ & $1-500$ & $1-750$ & $1-1000$ & $1-2000$ & $1-3000$ & $1-4000$ \\
\hline \multirow[t]{2}{*}{ 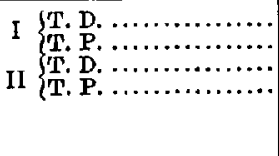 } & $\begin{array}{l}+++ \\
+++ \\
++t \\
++t\end{array}$ & $\begin{array}{l}++t \\
++t \\
++t \\
++t\end{array}$ & $\begin{array}{l}+++ \\
+++ \\
+++ \\
+++\end{array}$ & $\begin{array}{l}t++ \\
+++ \\
+++ \\
+++\end{array}$ & $\begin{array}{l}++ \\
++ \\
++ \\
++ \\
+\end{array}$ & $\begin{array}{l}+++ \\
+ \\
++ \\
+\end{array}$ & $\begin{array}{c}++t \\
++ \\
+\end{array}$ & $\begin{array}{l}++ \\
- \\
-\end{array}$ & $\begin{array}{l}\because \\
\because \\
\cdots\end{array}$ \\
\hline & \multicolumn{9}{|c|}{ T. P. Immune Serum } \\
\hline 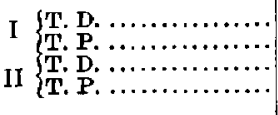 & $\begin{array}{l}+++ \\
+++ \\
+++ \\
++t\end{array}$ & $\begin{array}{l}+++ \\
+++ \\
++t \\
+++\end{array}$ & $\begin{array}{l}- \\
++t \\
+++\end{array}$ & $\begin{array}{l}\overline{-} \\
+\underline{-}\end{array}$ & $\begin{array}{l}- \\
++\end{array}$ & $\bar{z}$ & $\begin{array}{l}- \\
\overline{-}\end{array}$ & $\bar{z}$ & $\bar{z}$ \\
\hline
\end{tabular}

The macroscopic method of agglutination was used throughout this study. Suspensions of 24-hour sugar-free and dextrose agar slant cultures were employed to avoid the effects of differences in acidity in sugar-free and dextrose broth.

Table 1 shows characteristic results from the injection of 2 rabbits with suspensions of "T. D." and of 2 rabbits with correspondingly heavy suspensions of "T. P." From this table it appears (1) that a serum of higher titer is obtained by the injection of suspensions of killed typhoid bacilli of the "T. D." strain than by the injection of suspensions of B. typhosus of the "T. P." strain; and (2) that the dextrose strain is more readily agglutinated than the sugarfree strain, even with the heterologous serum. It would seem therefore that the presence of utilizable carbohydrate in media either had increased the amount of both agglutinogenic and agglutinable substances of this strain of typhoid bacilli, or, more likely, its absence had decreased the amount of these substances.

\section{OPSONINS}

A comparatively small number of observations were made upon the production of opsonins for "dextrose" and "sugar-free" strains by the injection of rabbits with suspensions of killed cultures of T. P. and T. D., respectively. Table 2 shows a characteristic result, 
from which it appears that the "dextrose" strain was more readily engulfed by leukocytes than the "sugar-free" strain, even in the presence of T. P. immune serum. But the percentage of leukocytes engaged in phagocytosis was greater in the presence of the homologous than of the heterologous serum.

TABLE 2

Effect of Bacterial Metabolism upon the Phagocytability of B. Typhosus

\begin{tabular}{|c|c|c|c|c|}
\hline \multirow[b]{2}{*}{ Culture } & \multicolumn{2}{|c|}{ T. D. Immune Serum } & \multicolumn{2}{|c|}{ T. I. Immune Serum } \\
\hline & $\begin{array}{l}\text { Phagocytic } \\
\text { Index }\end{array}$ & $\begin{array}{l}\text { Percentage of } \\
\text { Leukocytes Con- } \\
\text { taining Bacilli }\end{array}$ & $\begin{array}{c}\text { Phagocytic } \\
\text { Index }\end{array}$ & $\begin{array}{l}\text { Percentage of } \\
\text { Lenkocytes Con- } \\
\text { taining Bacilli }\end{array}$ \\
\hline $\begin{array}{llll}\text { T. } & \text { D. } & \cdots \ldots \ldots \\
\text { T. } & \text { P. } & \cdots \cdots\end{array}$ & $\begin{array}{l}3.7 \\
1.4\end{array}$ & $\begin{array}{l}59 \\
38\end{array}$ & $\begin{array}{l}2.6 \\
1.9\end{array}$ & $\begin{array}{l}38 \\
52\end{array}$ \\
\hline
\end{tabular}

\section{LYSINS}

An attempt was made to determine whether there was any difference in the lysinogenic properties of T. P. and T. D., and also to discover whether the two strains differed in any way in their susceptibility to bacteriolysis. The technic first described by Neisser ${ }^{10}$ was employed. The results obtained by using immune serum were very confusing and lacking in uniformity. The cause of this was found to be a variation in the amount of lysin in different specimens of normal guinea-pig or rabbit serum used as complement, and in the difference in the effect of this normal lysin on the dextrose and sugar-free strains. Hence, it was necessary to limit this study to the investigation of the susceptibility of these two strains to the lysins of normal serum.

The serum was not inactivated and was tested within 3 hours after the blood was drawn. The technic was as follows: Dilutions of $1: 10,1: 20$, etc., up to $1: 100$ were made in physiologic salt solution. One cubic centimeter of each dilution was placed in each of 2 test tubes. To each tube of one set of dilutions was added 1 c.c. of a suspension of the dextrose strain, made by inoculating one loopful of a 24-hour dextrose-broth culture into 50 c.c. of dextrose broth. To each tube of the other set there was added 1 c.c. of a suspension of the sugar-free strain, made by inoculating 2 or 3 loopfuls of a 24-hour sugar-free broth culture into 50 c.c. of broth. (The difference in number of loopfuls of culture used in the two instances was due to the difference in density of growth of the two strains in their respective media.) Each set of tubes was incubated for 3 hours. Agar plates were then made by pouring the cooled, melted agar into the mixture of bacillary suspension and serum dilution and thence into Petri dishes. The plates were then incubated for 24 hours. The amount of bacteriolysis was in inverse proportion to the number of colonies on these plates.

10. P. Ehrlich: Collected Studies on Immunity, 1906. 
As controls, 1 c.c. of each bacillary suspension was placed in each of 2 test tubes containing 1 c.c. of physiologic salt solution. Agar plates were made immediately, as described, from 1 tube of each diluted suspension. The other two tubes were incubated for 3 hours and plates poured at the end of that time. All four plates were incubated for 24 hours. The first two of the control plates indicated the number of bacilli in each of the suspensions at the beginning of the experiment; the last two showed the number to which these had increased when not hindered by the presence of a lytic serum.

Charts 1,2, and 3 show the effect of normal guinea-pig, rabbit, and human sera upon the T. P. and T. D. strains. From these charts it is seen that the dextrose strain is very much more easily destroyed by the lytic action of normal sera than is the sugar-free strain. Control tests showed that the reduction in the number of colonies on the plates poured from the serum mixtures was not due to agglutination. As shown in the charts, many of the plates were entirely sterile.

It may be objected that in all but one instance there were more bacilli per cubic centimeter to begin with in the suspension of the sugarfree strain than in the dextrose strain. But the greater rate of growth of T. D. would at least partially balance this. Furthermore, the number of bacilli present after 3 hours' incubation shows such a vast difference in the two sets of tubes that it hardly seems possible to account tor the result solely on the basis of a not very great initial difference in the density of the suspensions.

\section{ENDOTOXIN}

Theobald Smith long ago called attention to the fact that B. diphtheriae ${ }^{11}$ and $\mathrm{B}$. tetani ${ }^{12}$ do not form toxins in dextrose broth. The following single observation is presented because it suggests that the presence of dextrose in media may influence the toxicity of the endotoxin of B. typhosus. Suspensions in physiologic salt solution were made of cultures of T. D. and T. P. grown on dextrose and sugar-free agar hardened in 16-ounce French square bottles. Each suspension consisted of the growth on 3 such bottle-plates of the respective organism. They were made up to as nearly equal density as possible and equal volumes of each taken for further treatment.

To each suspension were added 3 c.c. of homologous immune (rabbit) serum and 2 c.c. of fresh normal rabbit serum for complement. The mixtures were incubated for 6 hours, and then passed through a Pasteur filter. One cubic centimeter of each filtrate inoculated into

11. Tr. Assn. Am. Phys., 1896, 11, p. 37.

12. Cited by Kendall: Jour. Med. Research, 1911, 24, p. 411. 
Bacterial Metabolism and Serum Reactions 505

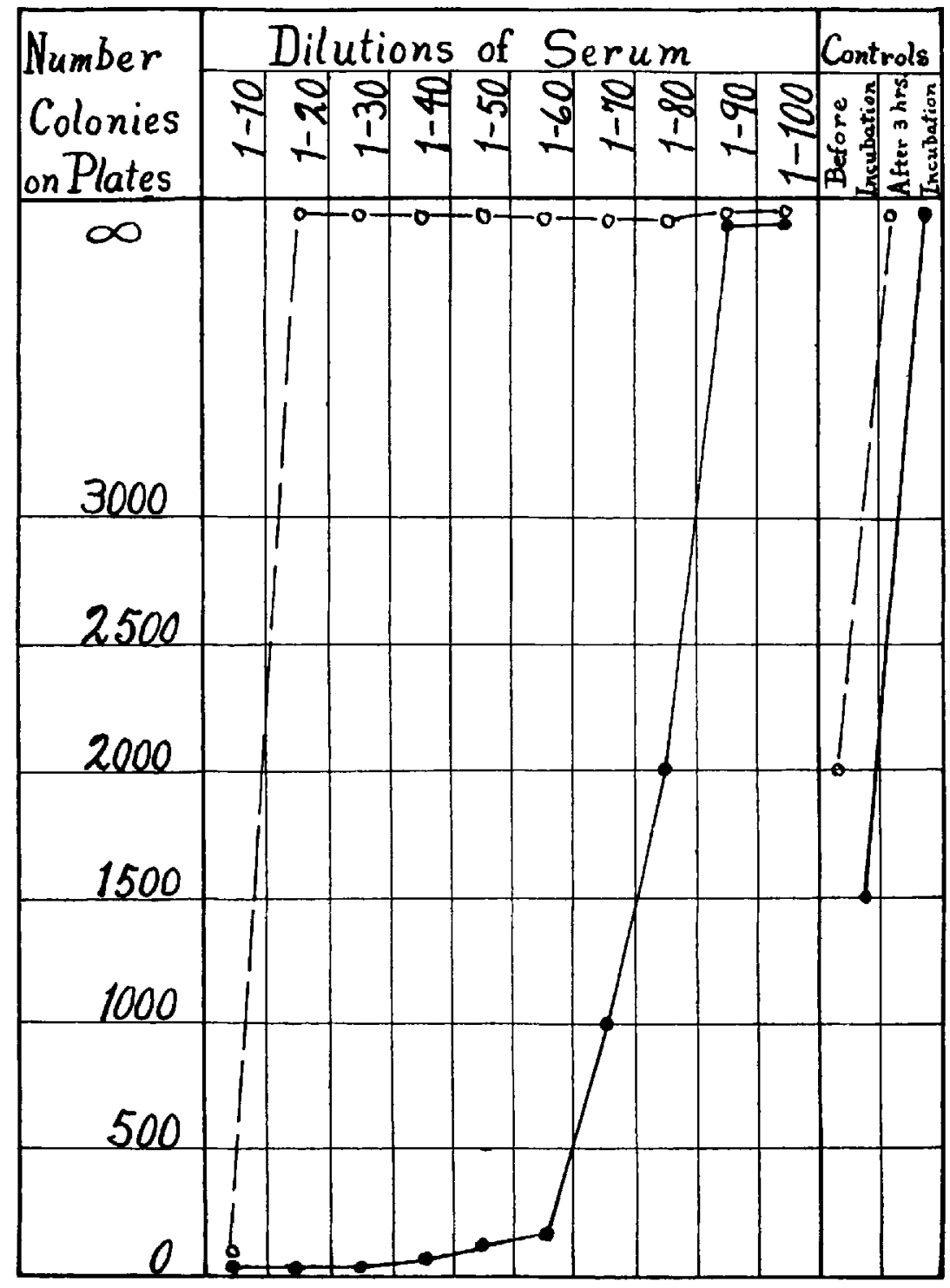

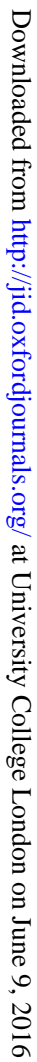

Chart 1.-The difference in susceptibility of 'T. D. and T. P. strains of B. typhosus to bacteriolysis by normal guinea-pig serum. The broken line represents T. P.; the solid line, T. D. 


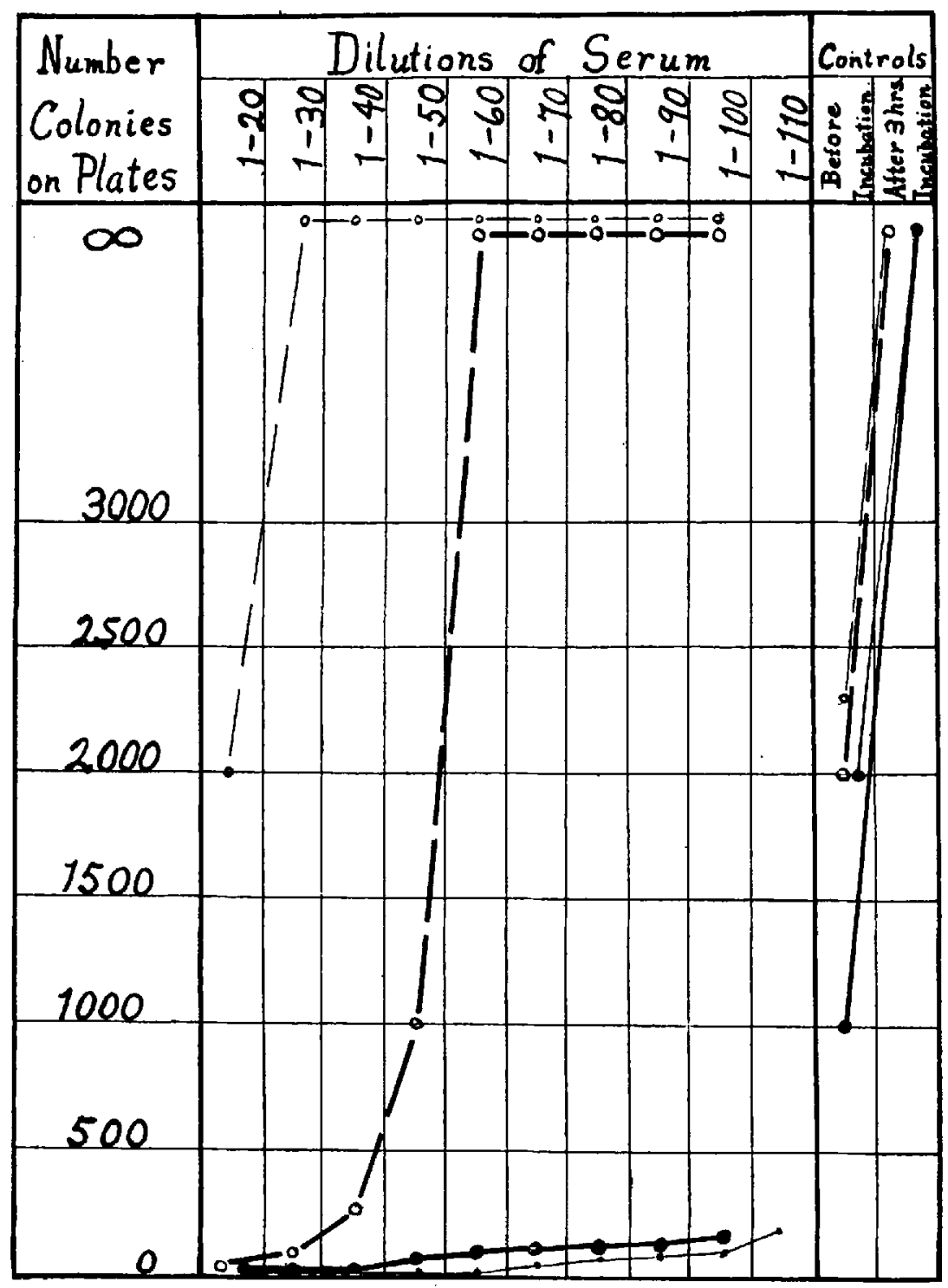

Chart 2.-The difference in susceptibility of $T$. D. and T. P. strains of $B$. typhosus to bacteriolysis by normal rabbit serum. The broken lines represent T. $P$, in Experiments 1 and 2. The solid lines represent $T, D$. in Experiments 1 and 2 . 
Bacterial Metabolism and Serum Reactions 507

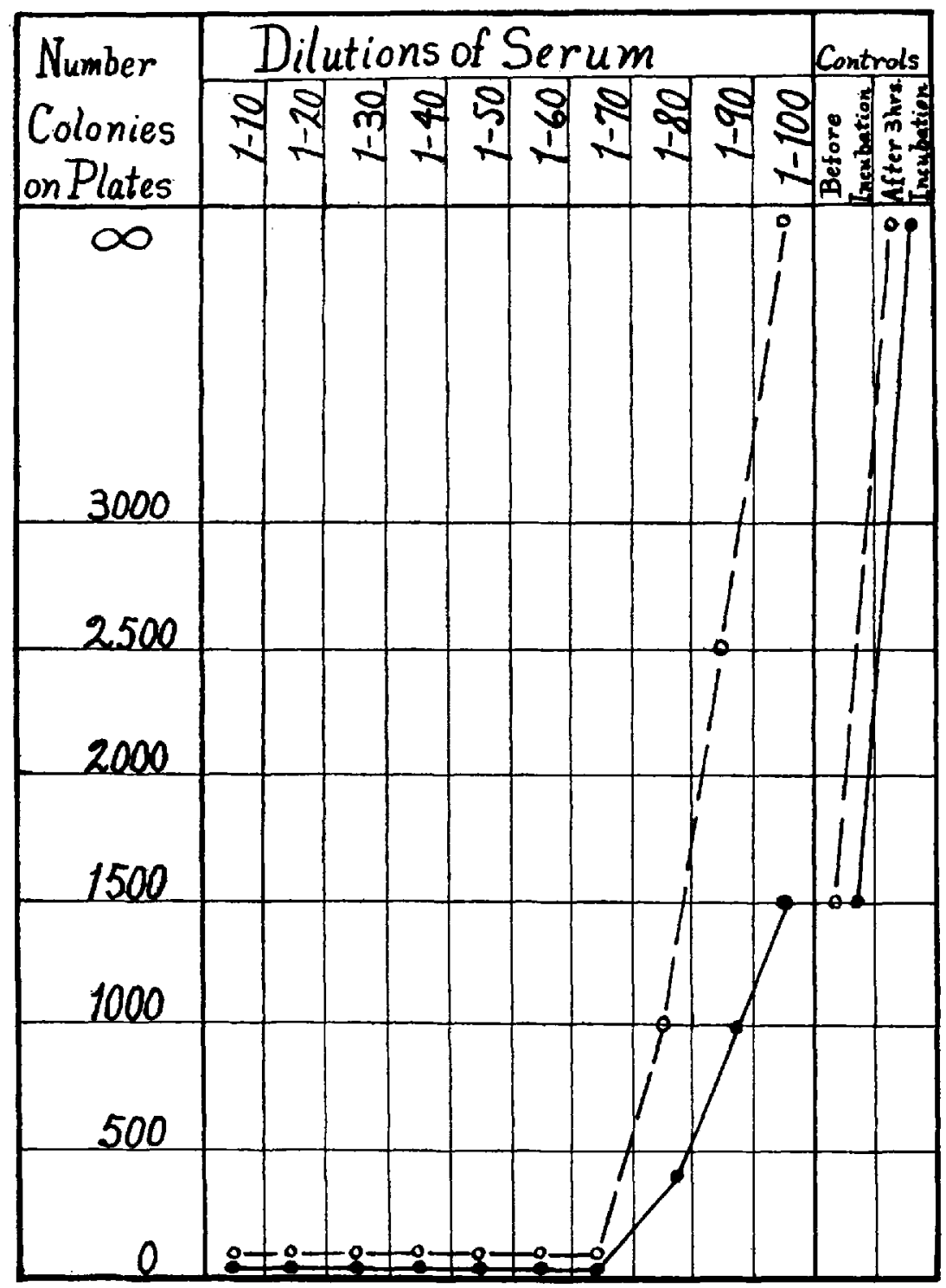

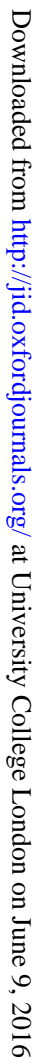

Chart 3.-The difference in susceptibility of T. D. and T. P. strains of B. typhosus to bacteriolysis by human serum. The individual from whom the serum was obtained received 3 doses of antityphoid vaccine 3 years previously. The broken line represents T. P.; the solid line, T. $D$. 
broth and incubated showed no growth. Two rabbits of approximately the same weight were injected intravenously with 12 c.c. of the filtrates. The results are shown in the following reports:

\section{RabBit 10.-Weight 1750 GRAms}

Jan. 29.-11:00 a. m.: Temperature 99.5 F.; $11: 35$ a. m.: 12 c.c. T. D. filtrate intravenously; 2:00 p. m.: Temperature $101.2 \mathrm{~F}$.

Jan. 30.-11:00 a. m.: Does not appear ill. Temperature 103.8 F. Leukocytes 75,800 (?) per cubic millimeter. Counting very difficult because of unavoidable tendency of leukocytes to form clumps. Polymorphonuclears 89.5\%. Lymphocytes 7.5\%. Large mononuclears $3.0 \%$. Two nucleated reds seen in counting 500 leukocytes.

Feb. 1.-11:00 a. m.: Temperature 101.2 F. Appears normal.

Feb. 2.-11:00 a. m.: Leukocytes 19,300 per cubic millimeter. Polymorphonuclears $35.0 \%$. Lymphocytes $41.0 \%$. Large mononuclears $16.3 \%$. Myelocytes (?) $2.7 \%$. Basophils $5.0 \%$. Two nucleated reds found in counting 400 leukocytes. Animal appears well.

\section{RabBit 11.-Weight 1800 Grams}

Jan. 29.-11:05 a. m.: Temperature 97.4 F.; $11: 30$ a. m.: 12 c.c. T. P. filtrate intravenously.

Jan. 30.-10:30 a. m.: Temperature $97.6 \mathrm{~F}$. Animal very ill. Leukocytes 41,400 (?). Accurate counting impossible on account of unavoidable tendency to form large clumps. 11:30 a. m.: Animal moribund. Chloroformed.

Autopsy: Heart normal. Lungs hyperemic in lower lobes. No enlarged lymph glands. Spleen of normal size and appearance. Peyer's patches not perceptibly enlarged. The liver shows several pin-point-sized whitish spots on cut surface. These are barely visible to the naked eye and are not surrounded by a zone of hyperemia. Otherwise, the liver shows nothing noteworthy. The kidneys are of about normal size. The edge of the cut surface tends to roll outward very slightly. The cut surface is moist, pale, and the cortical markings indistinct. The urinary bladder is distended with urine, which contains albumin and many granular casts.

Microscopic examination: The most striking change seen in the sections is the enormous number of lyaline thrombi in the vessels of all organs, especially in the lungs and liver. The minute whitish spots in the liver are found to be areas of necrosis infiltrated with polymorphonuclear leukocytes. These are within the lobules, perhaps a little nearer to the periphery than to the central vein. There is no vascular reaction around them. Similar areas are present in the cortex of the adrenal.

\section{DISCUSSION AND CONCLUSIONS}

From the results detailed here, it would seem that the presence of fermentable sugar in cultures of $B$. typhosus not only influences its metabolism, but may produce striking changes in the serologic reactions of the organism and may even affect the potency of its endotoxin. 
It is possible that this may be a factor in the favorable resulis reported by Coleman ${ }^{13}$ from his high calory diet in typhoid fever. The large carbohydrate component of the diet could hardly be expected actually to increase the blood agar, but it would lead to a greater storage of carbohydrate in the liver and tissues. It is not impossible that the presence of this greater store of carbohydrate may render the infecting strain of typhoid bacillus more susceptible to the action of the normal and immune lysins of the blood and may also reduce the potency of its endotoxin. So far as we are aware, there are no published records of repeated blood cultures on patients given the high calory diet.

13. Arch. Int. Med., 1915, 15, p. 887. 